\title{
Nitrate and ammonium proportions in sesame cultivation under irrigation with saline waters
}

\author{
Geovani Soares de Lima', Adaan Sudario Dias², Hans Raj Gheyi \\ Lauriane Almeida dos Anjos Soares', Reginaldo Gomes Nobre', \\ Francisco de Assis França Dantas da Silva ${ }^{5}$

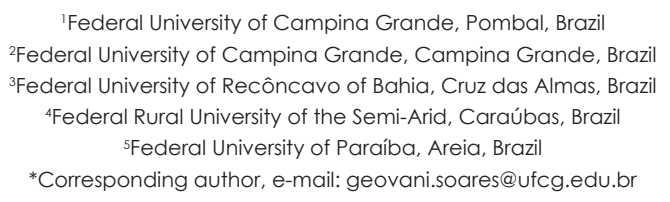

\begin{abstract}
This research was conducted with the aim of evaluating the water relations, growth and the production components of the sesame cv. CNPA G3, in function of the irrigation with waters of different salinities and fertilization with different proportions of nitrate $\left(\mathrm{N}-\mathrm{NO}_{3}{ }^{-}\right)$and ammonium $\left(\mathrm{N}-\mathrm{NH}_{4}{ }^{+}\right)$. The study was performed in drainage lysimeters in conditions of greenhouse, in the municipality of Campina Grande, PB, Brazil. The adopted design was in randomized blocks, in a factorial scheme of $5 \times 5$ with three repetitions, whose treatments were constituted of five levels of electrical conductivity of the irrigation water - ECW $\left(0.6 ; 1.2 ; 1.8 ; 2.4\right.$ and $\left.3.0 \mathrm{dS} \mathrm{m}^{-1}\right)$ and five proportions of nitrate and ammonium (200:0; 150:50; 100:100; 50:150; 0:200 $\mathrm{mg} \mathrm{kg}^{-1}$ of soil). The irrigation with $\mathrm{ECW}$ superior to $0.6 \mathrm{dS}^{-1}$ negatively affected the growth and production of the sesame; the fertilization with $\mathrm{N}_{-} \mathrm{NH}_{4}{ }^{+}$and $\mathrm{N}^{-\mathrm{NO}_{3}}{ }_{3}^{-}$in the proportion 200:0 resulted in a higher

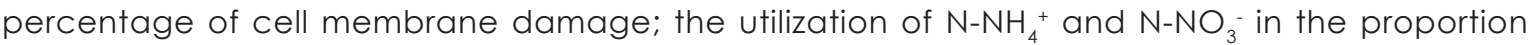
50:150 provided increase in the relative water content in the leaf blade and in the mass of a hundred seeds; $\mathrm{N}_{-} \mathrm{NO}_{3}$ and $\mathrm{N}-\mathrm{NH}_{4}{ }^{+}$proportions of $200: 0$ and $150: 50$ and water with $\mathrm{ECW}$ of 0.6 dS $\mathrm{m}^{-1}$ promoted the highest values for the content of chlorophyll $a$ and total number of sesame seeds.
\end{abstract}

Keywords: fertilization, salt stress, Sesamum indicum L.

\section{Introduction}

Sesame (Sesamum indicum L.) is an oleaginous plant which possesses a wide socioeconomic expression in Brazil due to its broad possibility of exploration, either in the national or in the international market. Furthermore, from the industrial point of view, its seeds might be utilized either in natura or for their oil content, commonly used in energetic and pharmaceutic products (Bezerra et al., 2010).

With the quantitative and qualitative decrease of the water resources in the semiarid region of the Brazilian northeast, due to the irregularity of pluvial precipitations and the occurrence of long drought periods, the occurrence of waters with high salt concentrations is common (Oliveira et al., 2010; Bezerra et al., 2010; Pessoa et al., 2012). The water salinity entails alterations in the absorption and utilization of nutrients, beside the excessive accumulation of ions in the protoplasm, which might lead to ionic toxicity, nutritional imbalance, or both (Calvet et al., 2013).

In the literature, incipient are the studies which identify the deleterious effects of the salt stress over the sesame crop (Abbasdokht et al., 2012; Bahrami \& Razmjoo, 2012; Suassuna, 2013). However, there exist controversies about its degree of tolerance to salt stress. Rhoades et al. (2000) and Suassuna, (2013), consider the sesame 
as sensible to water salinity. However, Azevedo et al. (2003), Abbasdokht et al. (2012) and Bahrami \& Razmjoo (2012) indicate it as tolerant to salt stress.

Thus, the search for management strategies capable of minimizing the negative effects occasioned by the irrigation with saline waters on sesame is of extreme importance, and among the alternatives stands out the fertilization with nitrogen (Lima et al., 2015). In the soil, nitrogen is available for the plants in different forms, however, the nitrate- $\mathrm{NO}_{3}-$ and the ammonium$\mathrm{NH}_{4}^{+}$are the two main mineral sources found in natural conditions (Cruz et al., 2008), being the form of absorption and assimilation of $\mathrm{N}$ by the plants, dependent on the proportion, species or the genotype (Hu et al., 2017).

The nitrogen in the ammoniacal form reduces the contents of $\mathrm{Ca}^{2+} \mathrm{e} \mathrm{Mg}^{2+}$ in the plant, decreasing the selective permeability of the root membrane, providing an increase in the chloride absorption, when it is found in higher concentration in the environment (Sousa et al., 2016). As to the providing of $\mathrm{N}$ in the form of $\mathrm{NO}_{3}$; it might decrease the production of grains and dry matter in plants which presented a low ability to reduce nitrate (Ali et al., 2007). However, the interaction between the ammoniacal and nitric sources provides distinct effects over the metabolism of the plants (Masclaux-Daubresse et al., 2010),

In this manner, it was aimed, with this study, to evaluate the water relations, the growth and the production components of sesame $\mathrm{cv}$. CNPA G3, in function of the irrigation with saline waters and fertilization with distinct proportions of nitrate and ammonium.

\section{Material and Methods}

The research was performed in recipients adapted as drainage lysimeters, under conditions of greenhouse, between November 2015 and February 2016, in the Center of Technology and Natural Resources of the Federal University of Campina Grande (CTRN/UFCG), located in the municipality of Campina Grande, Paraíba state, situated on the geographical coordinates $07^{\circ} 15^{\prime} 18^{\prime \prime}$ S latitude, 3552'28' of W longitude and average height of $550 \mathrm{~m}$.
The utilized experimental design was in randomized blocks in a $5 \times 5$ factorial arrangement, with three repetitions, whose treatments consisted of five levels of electrical conductivity of the irrigation water - ECW (0.6; $1.2 ; 1.8 ; 2.4$ and $3.0 \mathrm{dS} \mathrm{m}^{-1}$ ) and five proportions of nitrate and ammonium -NAP (200:0; 150:50; 100:100; 50:150; 0:200 $\mathrm{mg} \mathrm{kg}^{-1}$ of soil).

Each recipient was perforated at the base, to allow drainage, and coupled to a transparent drain of $4 \mathrm{~mm}$ diameter connected to its base. The extremity of the drain which was inside the recipient was wrapped with a nonwoven geotextile fabric (Bidim OP 30) to avoid obstruction of the soil material. Under each drain lied a plastic bottle for the collection of the drained water for estimation of water consumption by the plant.

The fillings of the lysimeters was performed by laying a layer of $0.5 \mathrm{~kg}$ of gravel followed by $26 \mathrm{~kg}$ of Eutrophic Grey Argisol of sandy loam texture, with the following chemical and physical characteristics, obtained through the methodologies proposed by Claessen (1997): exchangeable $\mathrm{Ca}^{2+}, \mathrm{Mg}^{2+}, \mathrm{Na}^{+}, \mathrm{K}^{+}$and $\mathrm{H}^{+}$, respectively, $7.41 ; 5.23 ; 1.82 ; 0.28 ; 3.07 \mathrm{cmol}_{\mathrm{C}}$ $\mathrm{kg}^{-1} ; 17.81 \mathrm{cmol}_{\mathrm{C}} \mathrm{kg}^{-1}$ of potential CEC; $1.79 \%$ of Organic matter; $48 \mathrm{mg} \mathrm{kg}^{-1}$ of $\mathrm{P}$ (resin or Mehlich or P-rem.); $\mathrm{pH}$ in water (1:2.5) of 5.95; Electrical conductivity of the saturation extract of 2,50 dS $\mathrm{m}^{-1}$; Sodium absorption ratio of 5,60 (mmol $\left.\mathrm{L}^{-1}\right)^{\frac{1}{2}} ; 656.6 ; 175.0 ; 168.4 \mathrm{~g} \mathrm{~kg}^{-1}$ of sand, silt, clay, respectively; water content at $33.42 \mathrm{kPa}=28.84 \%$ and at $1519.5 \mathrm{kPa}=10.42 \%$.

The sesame cultivar utilized in this study was the CNPA G3, for being a genetic material indicated for cultivation in the semiarid region of Brazil's northeast. It consists of a cultivar of average stature (up to $1.60 \mathrm{~m}$ ), crop cycle from 90 to 100 days, branched growth habit and uniform flowering and maturation. It presents one fruit per axil and seed of cream color. Furthermore, it possesses resistance to the angular leaf spot and susceptibility to cercosporiosis and macrophomina (Lima et al., 2013).

The irrigation waters with ECW 1.2; $1.8 ; 2.4$ and $3.0 \mathrm{dS} \mathrm{m} \mathrm{m}^{-1}$ were prepared through dissolution of chloride salts of sodium $(\mathrm{NaCl})$, calcium $\left(\mathrm{CaCl}_{2} \cdot 2 \mathrm{H}_{2} \mathrm{O}\right)$ and magnesium $\left(\mathrm{MgCl}_{2} \cdot 6 \mathrm{H}_{2} \mathrm{O}\right)$, 
in water of the local supply system (Campina Grande-PB), in the equivalent proportion of 7:2:1, for $\mathrm{Na}^{+}, \mathrm{Ca}^{2+}$ and $\mathrm{Mg}^{2+}$, respectively, considering the relation between $\mathrm{ECW}$ and the salts concentration $\left(10^{*} \mathrm{mmol}_{\mathrm{c}} \mathrm{L}^{-1}=\mathrm{ECW}\right.$ dS $\left.\mathrm{m}^{-1}\right)$, extracted from Richards (1954). The ECW level of $0.6 \mathrm{dS} \mathrm{m}^{-1}$ was obtained through the mixture of supply water with rainwater $(\mathrm{ECW}=0.02 \mathrm{dS}$ $\left.\mathrm{m}^{-1}\right)$. After preparation and calibration of the ECW, utilizing a portable conductivity meter, the waters were stored in plastic containers with 200 L capacity, properly protected.

Before the sowing, the water content in soil was elevated up to the field capacity ( 33.42 $\mathrm{kPa}$ ), utilizing respective water, according to the treatment. After the sowing, the irrigation was daily performed, applying in each lysimeter a volume of water as to maintain soil water content near to the field capacity, being the applied volume determined according to the water needs of the plants, estimated through the water balance: applied water volume minus the drained volume in the previous irrigation.

In each lysimeter were sown fifteen sesame seeds, $1.5 \mathrm{~cm}$ deep, being distributed in an equidistant arrangement. Twenty and thrity days after sowing (DAS), thinnings were performed, aiming to leave only one plant per lysimeter.

Fertilization based on $P$ and $K$ was performed according to Novais et al. (1991), being applied equivalent to $300 \mathrm{mg} \mathrm{kg}^{-1}$ of $\mathrm{P}_{2} \mathrm{O}_{5}$ and $150 \mathrm{mg} \mathrm{kg}^{-1}$ of $\mathrm{K}_{2} \mathrm{O}$, utilizing the single superphosphate and the potassium chloride, respectively. As $\mathrm{N}_{-} \mathrm{NO}_{3}$ source was utilized the calcium nitrate, and as $\mathrm{N}^{-\mathrm{NH}_{4}}{ }^{+}$source the ammonium chloride. The $\mathrm{P}$ was totally applied at the sowing, whilst the fertilizations with $\mathrm{K}$ and

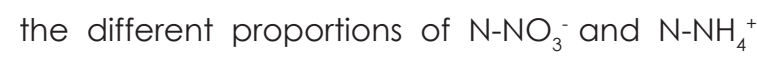
were parceeded out, being one third of the dosage of each nutrient applied in the sowing and, the remaining, in three equal applications, at intervals of ten days, being the first application performed at 25 DAS. To inhibit the nitrification of the ammoniacal $\mathrm{N}$, along with each application of ammonium chloride was applied a nitrification inhibitor, the dicyandiamide, in the equivalent

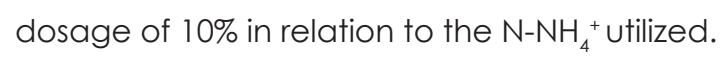

The effects of the treatments over the sesame crop were evaluated, through the percentage of the cell membrane damage $(\% \mathrm{D})$, relative water content in the leaf blade (RWC), contents of chlorophyll a $(\mathrm{Cl}$ a) and b $(\mathrm{Cl}$ b) and carotenoids (Car) at 40 DAS, and the growth was measured at 60 DAS, through stem diameter (SD) and plant height. As to the production components: total number of seeds per plants and the mass of a hundred seeds were evaluated at 100 DAS.

The \%D was evaluated with the purpose of determining the disruption capacity of the cell membrane under conditions of salt stress. Therefore, were collected, in the third leaf of the stem apex, 10 leaf disks of $113 \mathrm{~mm}^{2}$ of area, washed with distilled water aiming the removal of other electrolytes adhered to the leaflets, which were placed in beakers, with $50 \mathrm{~mL}$ of double-distilled water and hermetically sealed with aluminum paper. The beakers were kept at a temperature of $25^{\circ} \mathrm{C}$, for $90 \mathrm{~min}$, where the initial electrical conductivity (Ci) was proceeded. Following that, the beakers were placed in an oven with forced air ventilation and subjected to the temperature of $80^{\circ} \mathrm{C}$ for $90 \mathrm{~min}$, where the measurement of the final electrical conductivity (Cf) was performed. In this manner, the damage percentage in the cell membrane was obtained according to Scott Campos \& Thi (1997), according to the Eq.1:

In which:

$\% \mathrm{D}=$ percentage of cell membrane damage;

$$
\% \mathrm{D}=\frac{\mathrm{Ci}}{\mathrm{Cf}} \times 100
$$

$\mathrm{Ci}=$ initial electrical conductivity $\left(\mathrm{dS} \mathrm{m}^{-1}\right)$;

$\mathrm{Cf}=$ final electrical conductivity $\left(\mathrm{dS} \mathrm{m}^{-1}\right)$.

For the determination of the relative water content in the leaf blade, totally expanded leaves in the superior third of the plant were removed, sampling one leaf of each plant, and immediately determining the fresh mass (FM) of each leaf, avoiding water losses. At the following, these samples were placed in plastic bags, immersed in distilled water and stored for 24 hours. After this period, removing the water excess with paper towel, was obtained the turgid mass (TM) of the samples, which were placed in an oven (temperature $\approx 65 \pm 3^{\circ} \mathrm{C}$, until constant weight) for the obtaining the dry mass (DM) of the 
samples. The RWC determination was performed according with the methodology of Weatherley (1950), utilizing the Eq. 2.

$$
\operatorname{RWC}(\%)=\frac{(\mathrm{FM}-\mathrm{DM})}{(\mathrm{TM}-\mathrm{DM})} \times 100
$$

In which:

RWC = water relative content (\%);

$F M=$ fresh mass of leaf $(g)$;

$T M=$ turgid mass $(g)$;

$\mathrm{DM}=$ dry mass $(\mathrm{g})$;

The quantification of the contents of photosynthetic pigments (a e b chlorophylls and carotenoids ( $\left.\mu \mathrm{m} \mathrm{g}^{-1} \mathrm{FM}\right)$ ), was performed following the laboratory method suggested by Arnon (1949), through samples of 5 disks of the blade of the third mature leaf from the apex. From the extracts were determined the concentrations of chlorophyll and carotenoids in the solutions through spectrophotometer of absorbance (ABS) at wavelength of 470,646, and $663 \mathrm{~nm}$, using the equations: chlorophyll $a(\mathrm{Cl} . a)=12.21$ ABS663 - 2.81 ABS646; chlorophyll b (Cl. b) $=20.13$ ABS646 - 5.03 ABS663; Carotenoids (Car) $=(1000$ ABS470 $-1.82 \mathrm{Cl}$. $a-85.02 \mathrm{Cl}$. b)/198. The values obtained for the contents of chlorophylls $a, b$ and carotenoids in the leaves were expressed in $\mu \mathrm{m} \mathrm{g}^{-1}$ of fresh matter $\left(\mu \mathrm{m} \mathrm{g}^{-1} \mathrm{FM}\right)$.

The collected data were subjected to variance analysis through the $\mathrm{F}$ test, and, when significant, were performed regression analysis for the factor salinity of irrigation water and the test of comparison of means (Tukey at 0.05 of probability) for the proportions of nitrate and ammonium, utilizing the statistical software SISVAR (Ferreira, 2011). Through the normality analysis of the residues found in the present study (Table 1) the exploratory analysis of the data were performed, transforming them in $\sqrt{X}$.

\section{Results and Discussion}

Through the summary of the variance analysis (Table 1), the significant effect of the salt levels over the relative water content, content of chlorophyll a $(p<0.01)$, damage percentage in the cell membrane, content of chlorophyll $b$ and carotenoids $(p<0.05)$ were verified. For the factor proportions of $\mathrm{N}$-nitrate and $\mathrm{N}$-ammonium, a significant influence is verified for the \%D, RWC $(p<0.05)$ and $\mathrm{Cl} . a(p<0.01)$. As to the interactions between the factors (NS $\times$ NAP) the occurrence of significant effect is only observed for the content of chlorophyll a $(p<0.05)$.

Table 1. Summary of variance analysis of the percentage of cell membrane damage (\%D), relative water content (RWC), contents of chlorophyll a (Cl. a) and chlorophyll b (Cl. b) and carotenoids (Car) of sesame cv. CNPA G3 plants irrigated with saline waters and fertilized with different proportions of $\mathrm{N}$-nitrate and $\mathrm{N}$-ammonium, at 40 days after sowing.

\begin{tabular}{|c|c|c|c|c|c|c|}
\hline \multirow{2}{*}{ Source of variation } & \multirow{2}{*}{ DF } & \multicolumn{5}{|c|}{ Mean squares } \\
\hline & & $\% \mathrm{D}^{1}$ & RWC & Cl. a & Cl. b $b^{1}$ & Car \\
\hline Saline levels (SL) & 4 & $63.55^{*}$ & $890.59^{* *}$ & $30.89^{* *}$ & $49.65^{*}$ & $1.83^{*}$ \\
\hline Linear regression & 1 & $198.57^{*}$ & $3068.99^{* *}$ & $105.32^{* *}$ & $4.81^{*}$ & $4.81^{*}$ \\
\hline Quadratic regression & 1 & $46.82^{\mathrm{ns}}$ & $161.39^{\text {ns }}$ & $15.51^{*}$ & $0.82^{\text {ns }}$ & $0.82^{\text {n }}$ \\
\hline $\mathrm{N}$-nitrate and $\mathrm{N}$ - ammonium (NAP) & 4 & $121.66^{*}$ & $202.13^{*}$ & $25.12^{* *}$ & $19.63^{\text {ns }}$ & $0.80^{\text {ns }}$ \\
\hline Interaction (SL x NAP) & 15 & $50.82^{\text {ns }}$ & $305.88^{\text {ns }}$ & $9.74^{*}$ & $14.64^{\text {ns }}$ & $0.51^{\text {ns }}$ \\
\hline Blocks & 2 & $16.18^{\text {ns }}$ & $309.78^{\text {ns }}$ & $5.88^{\text {ns }}$ & $15.63^{\text {ns }}$ & $1.38^{\mathrm{n}}$ \\
\hline Residual & 49 & 27.41 & 91.00 & 3.01 & 102.61 & 0.39 \\
\hline CV $(\%)$ & & 17.87 & 17.34 & 13.95 & 19.63 & 22.44 \\
\hline
\end{tabular}

The irrigation with water of different saline levels significantly affected the \%D in the sesame cell membrane and, according to the regression equation (Figure 1A) an increment of $12.78 \%$ through unitary increase of the ECW is verified, resulting in an increment of $25.51 \%$ in the \%D of the plants subjected to ECW of 3.0 $\mathrm{dS} \mathrm{m}^{-1}$ in comparison to the plants irrigated with the water with lowest salinity level $\left(0.6 \mathrm{dS} \mathrm{m}^{-1}\right)$. It is verified from the results obtained for the $\% \mathrm{D}$
(Figure 1A), that as there was an increment in the ECW, the plants presented a higher liberation of ions (electrolytes), that is, a higher loss in integrity and destabilization of the cell membrane. Such phenomenon, in conditions of saline or water stress occurs due to the increase in the amount of active oxygen species (superoxides), free radicals and enzymes (Sharma et al., 2012). On the other hand, the increase in the concentration of electrolytes in leaf cells constitutes a mechanism 
which avoids tissue desiccation, given the reduction of the osmotic component of the leaf

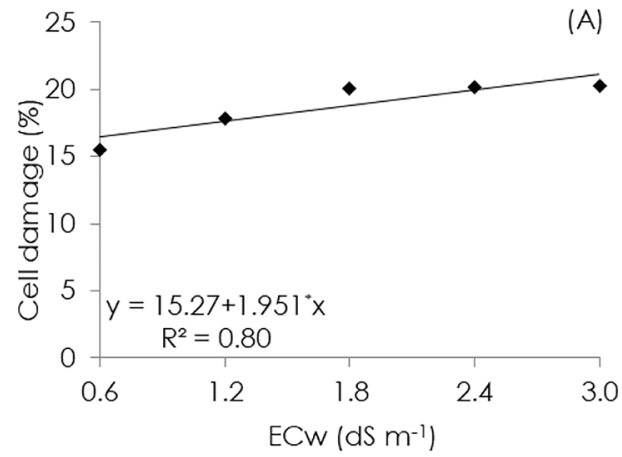

Figure 1. Percentage of cell membrane damage (\%D) of sesame cv. CNPA G3, in function of the electrical conductivity of the irrigation water - ECW (A) and of the different proportions of N-nitrate and N-ammonium (B), at 40 days after sowing. Means followed by the same letter do not differ from each other by Tukey's test $(p<0.05)$.

Analyzing the percentage of cell membrane damage in function of the fertilization with different proportions of $\mathrm{N}$-nitrate and $\mathrm{N}$-ammonium, it is verified through test of mean comparison (Figure 1B), that the sesame plants, when fertilized with nitrate and ammonium in the proportion of 0:200, statistically differ from those subjected to 200:0; $150: 50$ and 100:100. Comparing the remaining proportions of $\mathrm{N}_{-} \mathrm{NO}_{3}$ : $\mathrm{N}_{-} \mathrm{NH}_{4}^{+}(200: 0 ; 150: 50 ; 100: 100 ; 50: 150)$ it is observed that there was no significant difference within each other. According to Gronwald et al. (1993) the excessive absorption of the ammonium ion contributes to promote the electrochemical imbalance in the interior of the cells and of the intracellular $\mathrm{pH}$, which stimulates the extrusion of ions to the apoplast. Furthermore, it provokes alterations in the osmotic and hormonal balances of the plants and increases in the resistance to the water flow, which might promote an increment in the percentage of cell membrane damage.

As for the RWC (Figure 2A), a linear decrease is verified in function of the increase in the electrical conductivity of the irrigation water, being the decrease of $11.24 \%$ per unitary increment of ECW, corresponding to a decline of $27.99 \%$ in the RWC of the sesame plants which received water with $3.0 \mathrm{dS} \mathrm{m}^{-1}$ comparing with those which were irrigated with $0.6 \mathrm{dS} \mathrm{m}^{-1}$. In this manner, the highest relative water content observed in the plants kept under the lowest level of water salinity $\left(0.6 \mathrm{dS} \mathrm{m}^{-1}\right)$ is considered an important fact, seen that the RWC reflects the turgidity stage of the plant. On the other hand, this reduction observed in the RWC of the plants water potential (Fioreze et al., 2013).

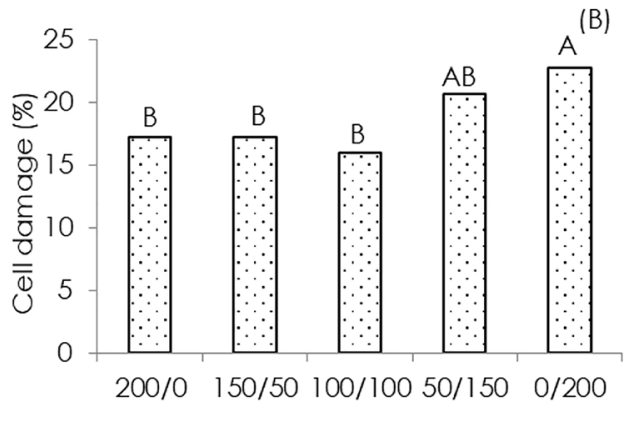

Proportions $\mathrm{N}-\mathrm{NO}_{3}^{-} / \mathrm{N}^{-} \mathrm{NH}_{4}^{+}$ irrigated with water of elevated salt levels might be related to the increase in the damages caused in the cell membranes (Figure 1A), due to the increment in the leaching of ions which affected the cell water potential and, consequently, promoted a loss in the cell turgescence. Thus, the decrease in the RWC might be an adaptation mechanism that, possibly, the plants developed, even allowing that, in low proportions, the absorption of water could occur (Garcia et al., 2009).

The RWC of the plants fertilized with 150:50 of $\mathrm{N}-\mathrm{NO}_{3}{ }^{-}: \mathrm{N}^{-} \mathrm{NH}_{4}{ }^{+}$statistically differed only in the plants which were subjected to the proportions of 50:150 of nitrate and ammonium (Figure 2B). The beneficial effect of the $\mathrm{N}-\mathrm{NO}_{3}$ obtained in the proportion of 150:50 for the sesame RWC, suggests the occurrence of a higher water flow in the plant, and this possibly resulted in an increase in the absorption of nutrients, mainly those transported through less selective channels in the plasmatic membrane (Holzschuh et al., 2009). In this context, some studies confirm that an adequate proportion of nitrate and ammonium might decrease the toxicity of this last ion in many crops, among them the wheat (Garnica et al., 2009) and Arabidopsis thaliana (Hachiya et al., 2012).

It is verified, in Figure $3 \mathrm{~A}$, that the interaction (NS x NAP) did affect the chlorophyll a content of the sesame plants. When analyzing the distinct proportions in function of the ECW, it is noted that the fertilization with the different proportions of $\mathrm{N}_{-} \mathrm{NO}_{3}{ }^{-}: \mathrm{N}_{-} \mathrm{NH}_{4}{ }^{+}$did not influence in a significant manner the chlorophyll a content 

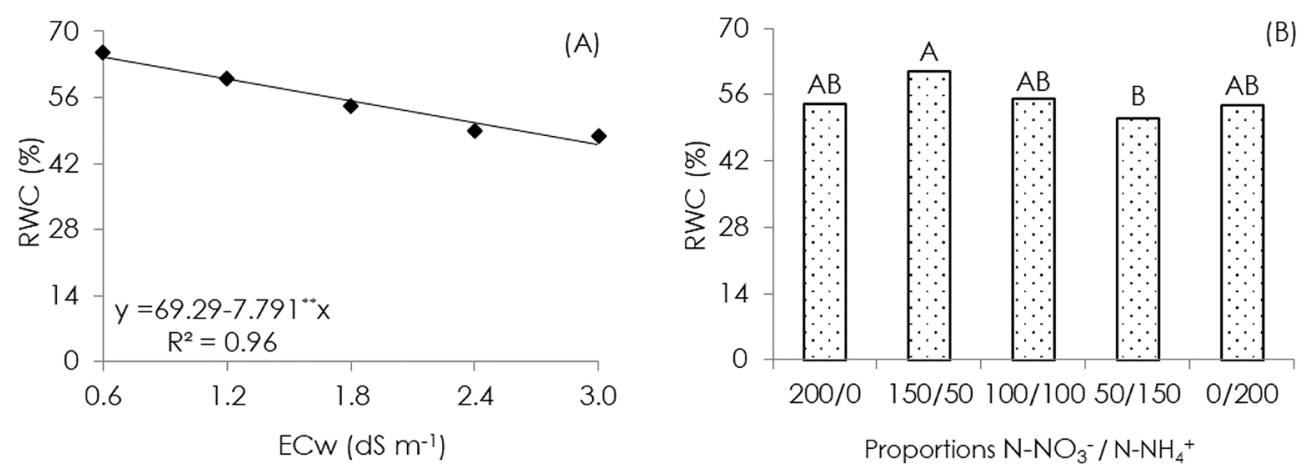

Figure 2. Relative water content (RWC) of sesame cv. CNPA G3 plants in function of the electrical conductivity of the irrigation water-ECW (A) and the different proportions of $\mathrm{N}$-nitrate and $\mathrm{N}$-ammonium (B), at 40 days after sowing. Means followed by the same letter do not differ from each other by Tukey's test $(p<0.05)$.

in sesame when irrigated with water of $0.6 ; 1.2$ and $1.8 \mathrm{dS} \mathrm{m}^{-1}$, respectively. However, there were significant differences of the proportions of 100:100 and 50:150 of $\mathrm{N}_{-} \mathrm{NO}_{3}{ }_{3}$ and $\mathrm{N}-\mathrm{NH}_{4}{ }^{+}$over the content of chlorophyll $a$ when the plants were subjected to $0: 200$ of $\mathrm{N}-\mathrm{NO}_{3}-\mathrm{N}^{-} \mathrm{NH}_{4}^{+}$and irrigated with $\mathrm{ECW}$ of $2.4 \mathrm{dS} \mathrm{m}^{-1}$ ). The plants cultivated in the highest saline level (3.0 dS $\left.\mathrm{m}^{-1}\right)$ presented significant difference for the content of chlorophyll a when fertilized with 50:150 and 0:200 of $\mathrm{N}-\mathrm{NO}_{3}{ }^{-} / \mathrm{N}^{-} \mathrm{NH}_{4}^{+}$ compared with the remaining proportions (200:0; $150: 50 ; 100: 100)$. It is yet seen through the test of averages comparison (Figure $3 \mathrm{~A}$ ) that the lowest values were obtained in the ECW levels of 2.4 and $3.0 \mathrm{dS} \mathrm{m}^{-1}$ and when the sesame plants received $\mathrm{N}$ only in the ammoniacal form (0:200).

The decrease in the content of chlorophyll $a$ in the plants subjected to water salinity might be attributed to the increase in the activity of the chlorophyllase enzyme, which degrades the chlorophyll, since the salt stress induces the degradation of the B-carotene and the reduction in the formation of zeaxanthin, producing a decrease in the content of carotenoids, pigments apparently involved in the protection against photoinhibition (Freire et al., 2013). Furthermore, the decrease in the contents of photosynthetic pigments might be a strategy and/or acclimation in which the reduction in the energy expenditure, carbon skeletons and necessary nutrients for the chlorophyll synthesis might favor other physiologic processes (Chaves et al., 2008).

As to the chlorophyll $b$ (Figure 3B), it is observed, according to the regression equation, linear and decrescent effect, with decrease in the content of $\mathrm{Cl}$. b of $18.82 \%$ through unitary increment of the ECW, that is, when subjected to irrigation with ECW $3.0 \mathrm{dS} \mathrm{m}^{-1}$, the plants presented an equivalent decrease of $50.93 \%$ in relation to those which were subjected to the lowest salinity level $\left(0.6 \mathrm{dS} \mathrm{m}^{-1}\right)$. The decrease in the content of chlorophyll b (Figure 3B) might be an indicative of destruction of the chloroplast structure and implies that, in elevated salt levels, the plant did not manage to maintain the integrity of its photosynthetic apparatus, degrading the chlorophyllase enzyme, which leads to reduction of the chlorophyll content (Jamil et al., 2007).

It is observed, in Figure 3C, that the irrigation with water of different salinities promoted linear decreases in the content of carotenoids of sesame plants of $10.39 \%$ per unitary increment of the salinity levels of the irrigation water, and according to the equation it is observed that when the plants were subjected to irrigation with com ECW of $3.0 \mathrm{dS} \mathrm{m}^{-1}$, there was a decrease in the content of carotenoids of $0.86 \mu \mathrm{m} \mathrm{g}^{-1}$ ) FM (26.62\% in comparison with those which were under ECW of $0.6 \mathrm{dS} \mathrm{m}^{-1}$. The degradation or inhibition of the carotenoid synthesis is one of the consequences of the alterations in the osmotic potential of water resulting from the excess of salts present in the water and/or soil, which promotes the photo-oxidation, entailing damages in the photosynthetic membranes, beside affecting other cell processes such as the division and cell expansion (Silva et al., 2014).

Based on the results of the variance analysis (Table 2), it is possible to verify the occurrence of significant effects $(p<0.01)$ of the factor saline levels over the stem diameter, plant height, mass of a hundred seeds and total number of seeds of the sesame plants. Concerning the 
distinct proportions of $\mathrm{N}_{-} \mathrm{NO}_{3}^{-}$and $\mathrm{N}_{-} \mathrm{NH}_{4}^{+}$, it is noted that there was a significant influence $(p<0.05)$ for the mass of a hundred seeds and
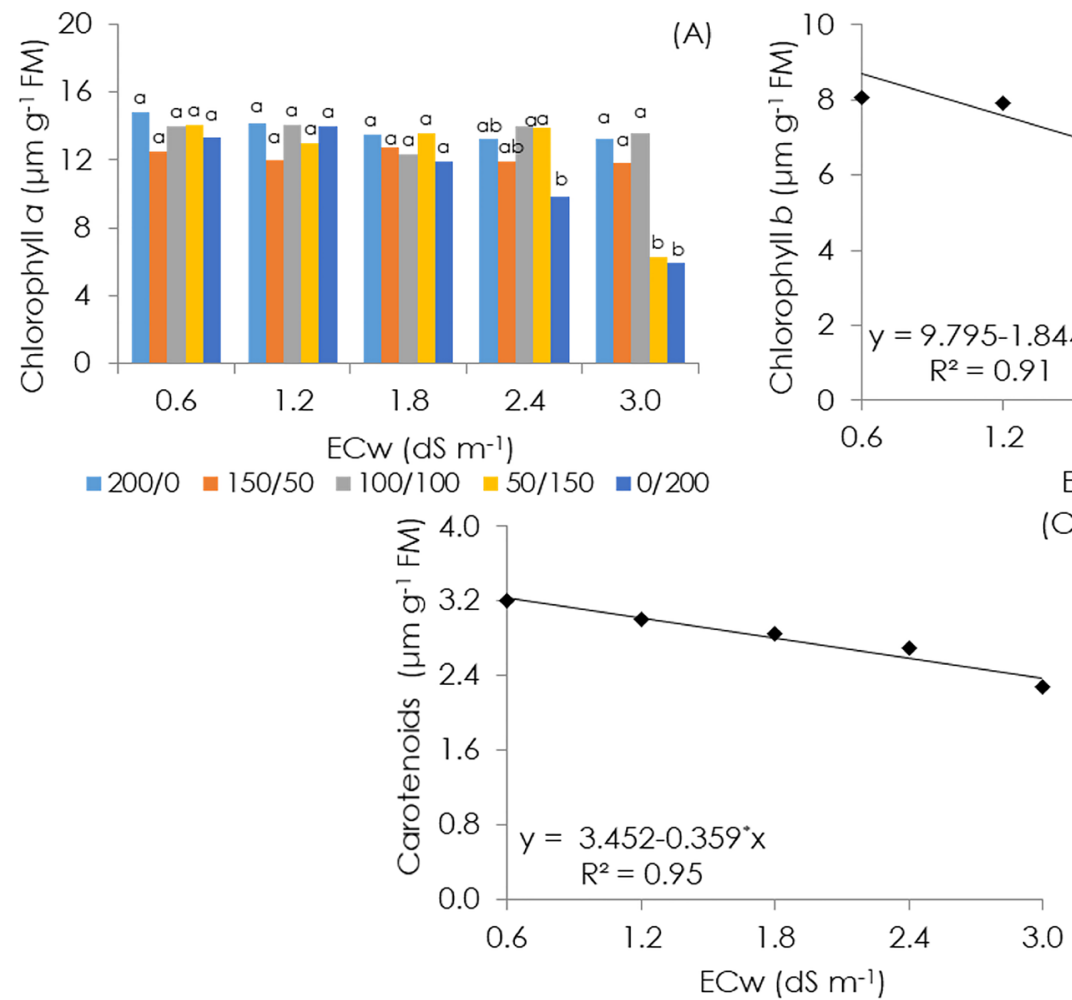

Figure 3. Content of chlorophyll a of sesame cv. CNPA G3 plants, in function of the interaction between the electrical conductivity of the irrigation water - ECW and the different proportions of N-nitrate and N-ammonium (A), content of chlorophyll b (B) and carotenoids (C) in function of the electrical conductivity of the irrigation water (ECW), at 40 days after sowing. Means followed by the same letter, comparing proportions of N-nitrate: $\mathrm{N}$-ammonium within the levels of electrical conductivity, do not differ from each other by Tukey's test $(p<0.05)$.

Table 2. Summary of the variance analysis for the stem diameter (SD), plant height (PH) at 60 days after sowing and mass of a hundred seeds (MHS) and total number of seeds (TNS) of the sesame cv. CNPA G3 plants irrigated with saline waters and fertilized with different proportions of $\mathrm{N}$-nitrate and $\mathrm{N}$-ammonium, at 100 days after sowing.

\begin{tabular}{|c|c|c|c|c|c|}
\hline \multirow{2}{*}{ Source of variation } & \multirow{2}{*}{ DF } & \multicolumn{4}{|c|}{ Mean squares } \\
\hline & & SD & $\mathrm{PH}$ & MHS & TNS $^{1}$ \\
\hline Saline levels (SL) & 4 & $105.63^{* *}$ & $12251.00^{* *}$ & $0.02^{* *}$ & $855440881.76^{* *}$ \\
\hline Linear regression & 1 & $382.00^{* *}$ & $46246.33^{* *}$ & $0.08^{* *}$ & $312041283.50^{* *}$ \\
\hline Quadratic regression & 1 & $20.61^{\mathrm{ns}}$ & $142.35^{\text {ns }}$ & $0.0001^{\text {ns }}$ & $7687159.90^{*}$ \\
\hline $\begin{array}{l}\text { N-nitrate and } \mathrm{N} \text { - ammonium } \\
\text { (NAP) }\end{array}$ & 4 & $3.98^{n s}$ & $208.51^{\mathrm{ns}}$ & $0.009^{*}$ & $7144334.82^{*}$ \\
\hline Interaction (SL x NAP) & 15 & $2.87^{\text {ns }}$ & $266.35^{\text {ns }}$ & $0.001^{\mathrm{ns}}$ & $3767958.73^{*}$ \\
\hline Blocks & 2 & $0.36^{\mathrm{ns}}$ & $49.01^{\mathrm{ns}}$ & 0.003 & $622171.56^{\mathrm{ns}}$ \\
\hline Residual & 49 & 2.06 & 233.52 & 0.001 & 1845747.55 \\
\hline CV (\%) & & 10.10 & 9.19 & 13.67 & 10.33 \\
\hline
\end{tabular}

The increase in the salinity of the irrigation water negatively affected the stem diameter of the sesame plants (Figure 4A) and according with the regression equation, a decrease of $14.02 \%$ is observed per unitary increase of ECW, equivalent to a decrease of $39.52 \%(7.23 \mathrm{~mm})$ in the SD of

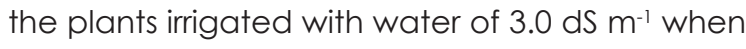
compared with those which were subjected to a

\section{ECW of $0.6 \mathrm{dS} \mathrm{m}^{-1}$.}

The decline in the SD of the sesame plants, in function of the increment in the ECW are reflexes of the lower water absorption by the plants, due mainly to the reduction of the osmotic potential of the soil solution provoked by the excess of salts affecting in a negative way the energetic status of the water on the plant; 
in this manner, the plant tends to spend a higher energy expenditure to absorb water and nutrients and, as a consequence, occurs a decrease in its growth, a fact observed in the stem diameter of sesame cv. CNPA G3 (Santos et al., 2012). Suassuna (2013) observed, when evaluating the

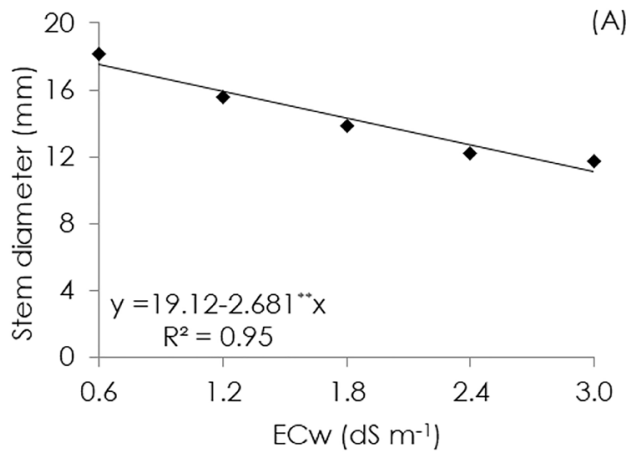

influence of the irrigation with water of electrical conductivity varying from 0.6 to $4.6 \mathrm{dS} \mathrm{m}^{-1}$ over the growth of sesame cv. CNPA G4, reduction in the stem diameter of $2.93 \%$ per unitary increment of $\mathrm{ECW}$, at 80 days after emergence.

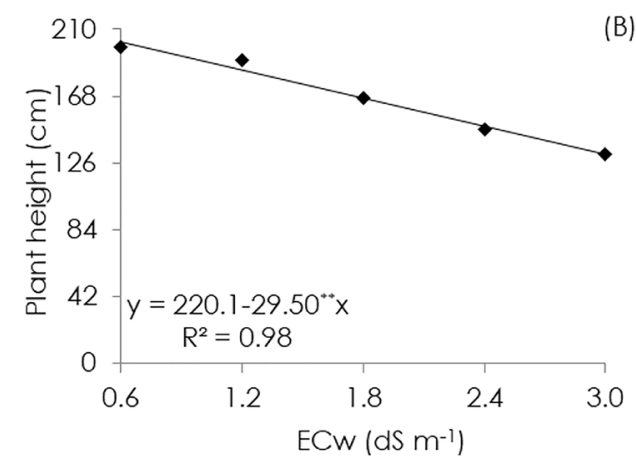

Figure 4. Stem diameter (A) and plant height (B) of the sesame cV. CNPA G3 plants, in function of the electrical conductivity of the irrigation water - ECW, at 60 days after sowing.

The height of the sesame cv. CNPA G3 plant was also influenced in a negative manner by the levels of ECW (Figure 4B), and according to the regression equation it is possible to observe a linear and decrescent effect in the $\mathrm{PH}$ of $13.40 \%$ per unitary increment of the electrical conductivity of the irrigation water. Through the regression equation it might also be verified that the plants, when subjected to ECW of $3.0 \mathrm{dS} \mathrm{m}^{-1}$, had reduction in the $\mathrm{PH}$ of $79.65 \mathrm{~cm}(37.70 \%)$ in comparison to those irrigated with $0.6 \mathrm{dS} \mathrm{m}^{-1}$. This negative effect was occasioned by the increase in the salinity of the irrigation water, decreasing the osmotic potential of the soil solution and leading to an accentuated decrease in the growth in terms of height, in the plants, due to the excess of salts restricting the turgor of expanding tissues (Boughalleb et al., 2012; Wang et al., 2012). Similar results were also verified by Suassuna (2013) in a study with six sesame genotypes (BRS Seda, CNPA-G2, CNPA-G3, CNPA-G4, Branquinha and Pretinha), observing that the growth in terms of height, in the plants decreased with increase in irrigation water salinity.

The increment in the levels of ECW linearly reduced the mass of a hundred (MHS) sesame seeds (Figure 5A), and according to the regression model there was decline in the MHS of $12.19 \%$ for each unitary increase of the ECW, that is, when subjecting the sesame plants to irrigation with water of $3.0 \mathrm{dS} \mathrm{m}^{-1}$, there was a decrease in the MHS $0.096 \mathrm{~g}$ (31.57\%), when compared to those which were being irrigated with water of $0.6 \mathrm{dS} \mathrm{m}^{-1}$. The decrease in the MHS is justified by the fact that the increase in the water salinity caused an expressive damage in the sesame growth, observed by the decline in the stem diameter (Figure 4A) and plant height (Figure $4 B)$, reducing, the MHS and, consequently, the final production of seeds. In this context, Assis Júnior et al. (2007) report that the reduction in the production of the plants under salinity occurs due to lags in the rate of the liquid assimilation of carbon, associated to osmotic effects and the accumulation of potentially toxic ions $\left(\mathrm{Na}^{+}\right.$and $\mathrm{Cl})$ in the leaf tissues.

The mass of a hundred sesame seeds significantly varied in function of the different proportions of $\mathrm{N}^{-\mathrm{NO}_{3}}$ and $\mathrm{N}^{-} \mathrm{NH}_{4}^{+}$(Figure $5 \mathrm{~B}$ ). It might be seen that the MHS was significantly superior in the plants subjected to fertilization

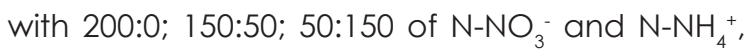
obtaining the mean value of $0.277 ; 0.275$ and $0.251 \mathrm{~g}$, respectively, statistically differing only from those plants which received 0:200 10.215 g). When analyzing the different proportions of nitrate and ammonium (Figure 5B), it is possible to observe, considering the absolute values of the MHS, that the difference between the treatment with highest (200:0) and lowest (0:200) mass of a hundred sesame seeds, was of the order of $22.38 \%$ ( $\left.0.062 \mathrm{~g} \mathrm{plant}^{-1}\right)$. In this manner, the importance of the nitric fertilization in sesame production is evidenced. On the other hand, this 


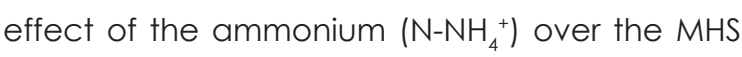
has been related to the utilization need of the carbohydrates primarily produced for the quick assimilation of the absorbed ammonium, with the purpose of avoiding its accumulation and consequent toxicity problems (Cruz et al., 2008).

Through the unfolding of the effect of the electrical conductivity of the irrigation water and the different proportions of $\mathrm{N}$-nitrate and $\mathrm{N}$-ammonium (Figure 5C), it is observed that the salt stress, at its highest level, reduced the total number of seeds in relation to those plants without salt stress, a reduction of $83.11 \%$, being reduced from 6572.8 seeds to 1109.8 seeds plant ${ }^{-1}$ on average independently of $\mathrm{N}-\mathrm{NO}_{3}-\mathrm{N}-\mathrm{NH}_{4}$
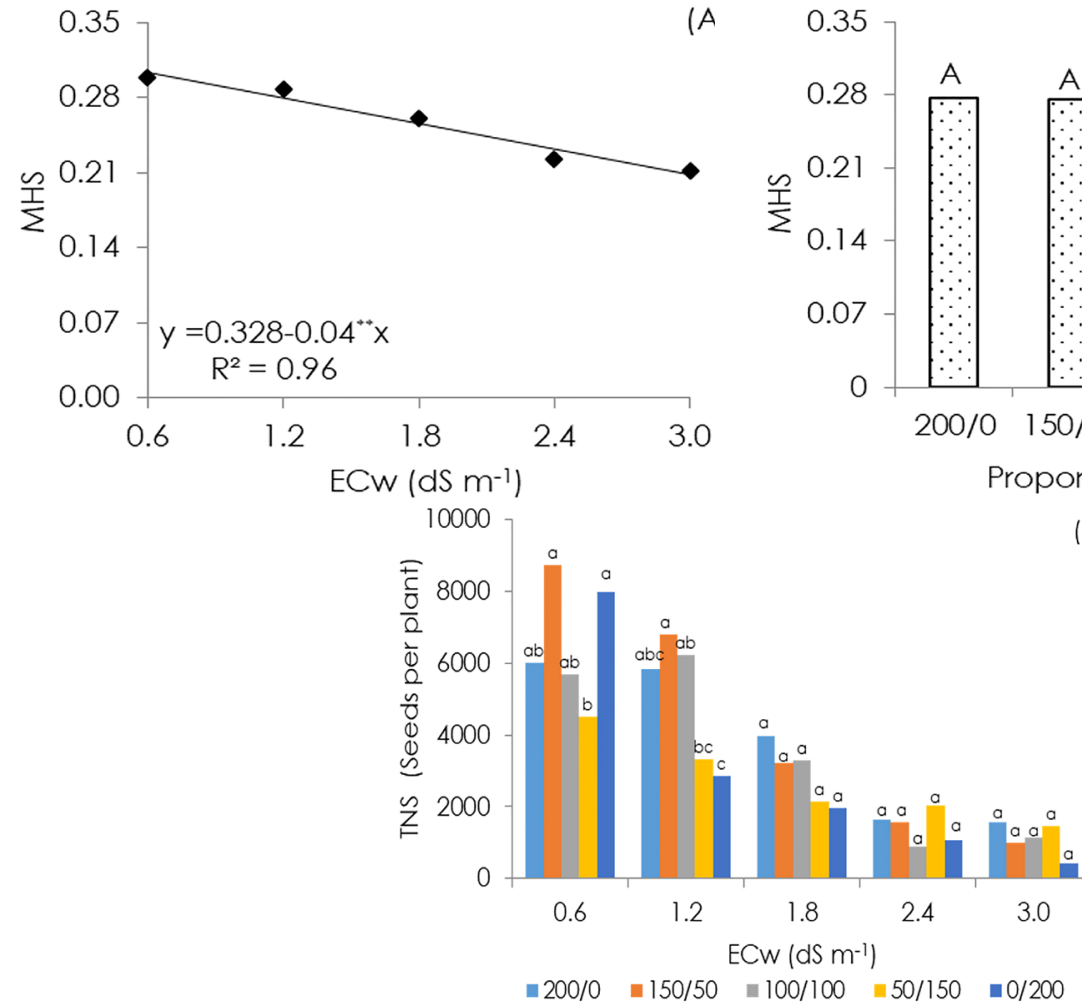

Figure 5. Mass of a hundred seeds (MHS) of the sesame cv. CNPA G3 plants, in function of the electrical conductivity of the irrigation water - ECW (A) and of the different proportions of N-nitrate and N-ammonium (B) and total number of seeds TNS (C) in function of the interaction between the ECW and the proportions of N-nitrate and $\mathrm{N}$-ammonium, at 100 days after sowing. Means followed by the same letter, comparing proportion of $\mathrm{N}$-nitrate: $\mathrm{N}$-ammonium in each level of electrical conductivity, do not differ from each other by Tukey's test $(p<0.05)$.

\section{Conclusions}

The irrigation with water of electrical conductivity superior to $0.6 \mathrm{dS} \mathrm{m}^{-1}$ negatively affects the growth and the components of production of sesame ;

The fertilization with $\mathrm{N}-\mathrm{NH}_{4}{ }^{+}$and $\mathrm{N}-\mathrm{NO}_{3}{ }^{-}$in the proportion 200:0 results in a higher percentage of cell membrane damage and lower mass of a hundred seeds of the sesame cv. CNPA G3 proportion. It might also be pointed, in Figure 5C, differences between the proportions of $\mathrm{N}$-nitrate and $\mathrm{N}$-ammonium only in the lowest saline levels

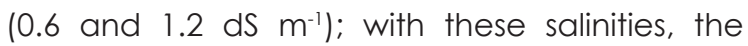
fertilization with the proportion of 150:50 of $\mathrm{N}^{-\mathrm{NO}_{3}}{ }_{3}$ : ${\mathrm{N}-\mathrm{NH}_{4}+}^{+}$allowed a higher total number of seeds (8719 and 6779 seeds per plant, respectively). According to Andrade et al. (2001), when both nitrogen sources $\left(\mathrm{NH}_{4}^{+}\right.$e $\left.\mathrm{NO}_{3}{ }^{-}\right)$are provided, the activity of the reductase enzyme of the nitrate is significantly increased, indicating a certain stimulatory action of the ammonium ion in the enzyme activity, a fact which justifies the higher total number of seeds (Figure $5 \mathrm{C}$ ) obtained in the

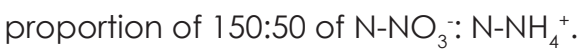

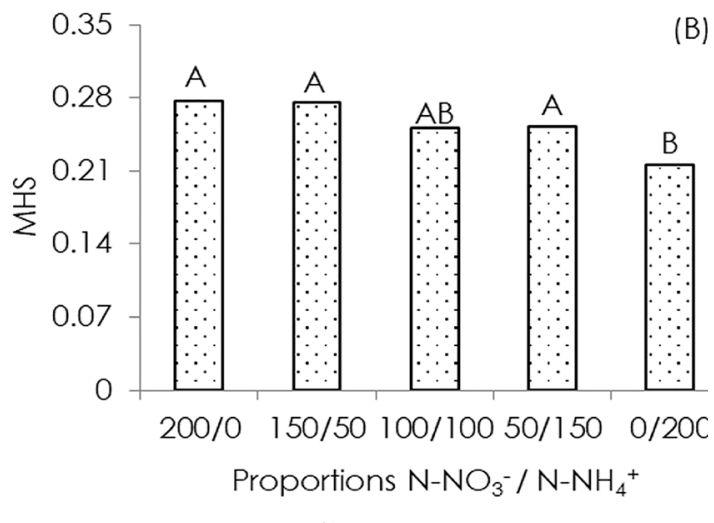

(B)

(1 


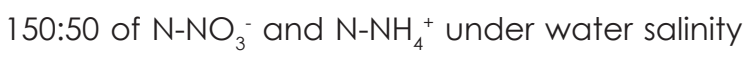
of $0.6 \mathrm{dS} \mathrm{\textrm {m } ^ { - 1 }}$, respectively.

\section{Acknowledgments}

To the National Program of PostDoctorate (PNPD/CAPES/UFCG), for granting the scholarship to the first author and to the National Institute of Science and Technology in Salinity INCTSal, for funding the project.

\section{References}

Abbasdokht, H., Ashrafi, E., Taheri, S. 2012. Effects of different salt levels on germination and seedling growth of sesame (Sesamum indicum L.) cultivars. Technical Journal of Engineering and Applied Sciences 2:309-313.

Ali, A., Sivakami, S., Raghuram, N. 2007. Effect of nitrate, nitrite, glutamate, glutamine and 2-oxoglutarate on RNA, levels and enzyme activities of nitrate reductase and nitrite reductase in rice. Physiology and Molecular Biology of Plants 13:17-25.

Andrade, S.R.M., Sant'Anna, R., Cambraia, J., Mosquim, P.R. 2001. Efeito da proporção de $\mathrm{NH}_{4}^{+} / \mathrm{NO}_{3}^{-}$na distribuição de nitrato e na atividade in vitro da redutase do nitrato em plantas de Panicum maximum. Planaltina, Embrapa Cerrados. 16p. (Boletim de pesquisa e Desenvolvimento, 12).

Assis Júnior, J.O., Lacerda, C.F., Silva, F.B., Francisco Silva, L.B., Bezerra, M,A., Gheyi, H.R. 2007. Produtividade do feijão-de-corda e acúmulo de sais no solo em função da fração de lixiviação e da salinidade da água de irrigação. Revista Brasileira de Engenharia Agrícola 27:702713.

Azevedo, M. R. de Q.A., Almeida, F. de A. C.; Gouveia, J.P.G. de; Azevedo, C.A.V. de; Silva, M.M. da; Pordeus, R. V. 2003. Germinação e vigor no desenvolvimento inicial do gergelim: Efeito da salinidade da água de irrigação. Revista Brasileira de Produtos Agroindustriais 5:167-172.

Bahrami, H.; Razmjoo, J. 2012. Effect of salinity stress $(\mathrm{NaCl})$ on germination and early seedling growth of ten sesame cultivars (Sesamum indicum L.). International Journal of AgriScience 2:529-537.

Bezerra, A.K.P., Lacerda, C.F.de, Hernandez, F.F.F., Silva, F.B. da, Gheyi, H.R. 2010. Rotação cultural feijão caupi/milho utilizando-se águas de salinidades diferentes. Revista Ciência Rural 40:1075-1082.

Bezerra, S.A., Dantas Neto, J., Azevedo, C.A.V. de, Silva, M.B.R., Silva, M.M. da. 2010. Produção do gergelim cultivado sob condições de estresse hídrico e diferentes doses de adubação. Engenharia Ambiental 7:156-165.

Boughalleb, F., Hajlaou, I. H., Denden, M. 2012. Effect of salt stress on growth, water relations, solute composition and photosynthetic capacity of hero-halophyte Nitraria retusa L. Environmental Research Journal 6:1-13.

Calvet, A. S. F., Pinto, C. M., Lima, R. E. M., MaiaJoca, R.P.M., Bezerra, M.A. 2013. Crescimento e acumulação de solutos em feijão-caupi Irrigado com águas de salinidade crescente em diferentes fases de desenvolvimento. Revista Irriga 18:148-159.

Chaves, M.M, Flexas, J, Pinheiro, C. 2008. Photosynthesis under drought and salt stress: Regulation mechanisms from whole plant to cell. Annals of Botany 125:1-10.

Claessen, M. E. C. (Org.). Manual de métodos de análise de solo. 2.ed. rev. atual. Rio de Janeiro: Embrapa CNPS, 1997. 212p. Documentos, 1.

Cruz, J. L., Pelacani, C.R., Araújo, W.L. 2008. Influência do nitrato e do amônio sobre a fotossíntese e a concentração de compostos nitrogenados em mandioca. Ciência Rural 38:643-649.

Ferreira, D.F. 2011. Sisvar: A computer statistical analysis system. Revista Ciência e Agrotecnologia 35:1039-1042.

Fioreze, S.L., Rodrigues, J.D., Carneiro, J.P.C., Silva, A.A., Lima, M.B. 2013. Fisiologia e produção da soja tratada com cinetina e cálcio sob déficit hídrico e sombreamento. Pesquisa Agropecuária Brasileira 48:1432-1439.

Freire, J.L. de O., Cavalcante, L.F., Nascimento, R. do, Rebequi, A.M. 2013. Teores de clorofila e composição mineral foliar do maracujazeiro irrigado com águas salinas e biofertilizante. Revista de Ciências Agrárias 36:57-70.

Garcia, G. de O., Martins Filho, S., Nazário, A. A., Moraes, W. B., Gonçalves, I. Z., Madalão, J. C. 2009. Estresse hídrico e salino na produção relativa e potencial de água na folha do feijoeiro. Revista Irriga 14:470-480.

Garnica, M., Houdusse, F., Yvin, J.C., GarciaMina, J.M. 2009. Nitrate modifies urea root uptake and assimilation in wheat seedlings. Journal of the Science of Food and Agriculture 89:55-62.

Gronwald, J.W., Jourdan, S.W., Wyse, D.L., Somers, D.A., Magnusson, M.U. 1993. Effect of ammonium sulfate on absorption imazethapyr by quackgrass (Elytrigia repens) and maize (Zea mays) cell suspension cultures. Weed Science $41: 325-334$. 
Hachiya, T., Watanabe, C.K., Fujimoto, M., Ishikawa, T., Takahara, K., Kawai-Yamada, M., Uchimiya, H., Uesono, Y., Terashima, I., Noguchi, K. 2012. Nitrate addition alleviates ammonium toxicity without lessening ammonium accumulation, organic acid depletion and inorganic cation depletion in Arabidopsis thaliana shoots. Plant and Cell Physiology 53:577591.

Holzschuh, M.J., Bohnen, H., Anghinoni, I., Meurer, E.J., Carmona, F. de C., Costa, S.E.V.G.de A. 2009. Resposta do arroz irrigado ao suprimento de amônio e nitrato. Revista Brasileira de Ciência do Solo 33: 1323-1331.

Jamil, M., Rehman, S., Lec, K. J., Kim, J.M., Kim, H.S., Rha, E.S. 2007. Salinity reduced growth PS2 photochemistry and chlorophyll content in radish. Scientia Agrícola 64:111-118.

Lima, M. S. R.; Rocha, M. S. Beltrão, N. E. M. Produção de sementes de gergelim In: Beltrão, N. E. M.; Ferreira, L. L. F.; Queiroz, N. L.; Porto, V. C. N. (Org.) O gergelim e seu cultivo no semiárido brasileiro. IFRN, Natal, Brasil. 2013, Cap. 6, p. 85 $-101$.

Masclaux-Daubresse, C., Daniel-Vedele, F., Dechorgnat, J., Chardon, F., Gaufichon, L., Suzuki, A. 2010. Nitrogen uptake, assimilation and remobilization in plants: Challenges for sustainable and productive agriculture. Annals of Botany 105:1141-1157.

Novais, R. F.; Neves, J. C. L.; Barros, N. F. Ensaio em ambiente controlado. In: Oliveira, A. J. (ed.) Métodos de pesquisa em fertilidade do solo. Brasília: Embrapa-SEA, 1991. p.189-253.

Oliveira, F.A. de, Oliveira, F.R.A. de, Campos, M. de S., Oliveira, M.K.T. de, Medeiros, J.F. de, Silva, O.M. dos P. 2010. Interação entre salinidade e fontes de nitrogênio no desenvolvimento inicial da cultura do girassol. Revista Brasileira de Ciências Agrárias 5:479-484.

Pessoa, L.G.M., Freire, M.B.G. dos S., Freire, F.J., Menezes, D. 2012. Crescimento de cebola irrigada com águas salinas em solos do semiárido de Pernambuco. Revista Brasileira de Ciências Agrárias 7:27-534.

Rhoades, J., Kandiah, A., Mashali, A.M. Uso de águas salinas para produção agrícola. Campina Grande: UFPB, 2000. 117p. Estudos FAO Irrigação e Drenagem 48.

Richards, L. A. Diagnosis and improvement of saline and alkali soils. Washington: U. S. Department of Agriculture, 1954. 160p. (USDA, Agriculture Handbook, 60).

Santos, B. dos., Ferreira, P.A., Oliveira, F.G. de., Batista, R.O., Costa, A.C., Cano, M.A.O.
2012. Produção e parâmetros fisiológicos do amendoim em função do estresse salino. Idesia (Arica) 30:69-74.

Scotti Campos, P., Thu PhanThi, A. 1997. Effect of abscisic acid pretreatment on membrane leakage and lipid composition of Vigna unguiculata leaf discs subject to ormotic stress. Plant Science 130:11-18.

Sharma, P., Jha, A.B., Dubey, R.S., Pessarakli, M. 2012. Reactive oxygen species, oxidative damage, and antioxidative defense mechanism in plants under stressful conditions. Journal of Botany 2012:1-26.

Silva, M.A., Santos, C.M. dos, Vitorino, H. dos S., Rhein, A.F. de L. 2014. Pigmentos fotossintéticos e índice Spad como descritores de intensidade do estresse por deficiência hídrica em cana-deaçúcar. Bioscience Journal 30: 173-181.

Sousa, J.R.M., Gheyi, H.R., Brito, M.E.B., Xavier, D.A., Furtado, G.F. 2016. Impact of saline conditions and nitrogen fertilization on citrus production and gas exchanges. Revista Caatinga 29:415-424.

Suassuna, J.F. 2013. Tolerância de genótipos de gergelim ao estresse salino. 126f. (Tese Doutorado) - Universidade Federal de Campina Grande, Campina Grande, Brasil.

Wang, W.Y., Yan, X.F., Jiang, Y., Qu, B., Xu, Y.F. 2012. Effects of salt stress on water content and photosynthetic characteristics in Iris lactea var. Chinensis seedlings, Middle-East Journal of Scientific Research 12:70-74.

Weatherley, P.E. 1950. Studies in the water relations of the cotton plant. I- The field measurements of water deficits in leaves. New Phytologist 49:81-97. 